\title{
provincial professional news
}

\section{Association of British Columbia Foresters Committees and Terms of Reference.}

1. ACT AND BY-LAWS

\author{
Chairman: H. B. Forse, \\ Wm. Hall, \\ Wm. Bishop.
}

a) Examine suggestions for changes to the November, 1967, draft Act and ByLaws, and incorporate those which have merit. If major changes are proposed, these should be submitted to the membership for a vote.

b) Arrange for a review by our legal counsel, presentation to Attorney-General's Department, sponsoring as a public bill, and all further action required to obtain passage of a new Act and By-laws at the 1969 winter session of the legislature.

2. APPLICATIONS

Chairman: W. G. Burch \& Don Grant.

a) Examine all applications and be prepared to recommend appropriate action to Council on each.

b) Distribute, possibly along with the meeting agenda, a brief summary of vital facts about each candidate, for Council members to study before the meeting.

3. CIF LIAISON

$$
\begin{aligned}
\text { Chairman: A. Scholefield, } \\
\text { H. Bancroít, } \\
\text { D. Bakewell. }
\end{aligned}
$$

a) Establish or maintain contact, either directly or through Association members, with the B.C. Sections of the CIF.

b) Advise Council of CIF activities of interest to the Association, and recommend any cooperative action which the Association might take.
4. DISCIPLINE AND ETHICS

Chairman: H. G. Bancroft,

R. Wellwood.

a) Examine complaints, originating from Council or Association members, which concern possible violations of the Act, the By-laws, or the Code of Ethics, by Association members or by non-members.

b) Assemble all pertinent information and recommend proper action to Council.

c) Maintain strict confidence and security in all Committee affairs.

d) If deemed advisable by the Committee, establish a record of precedent as a guide in future discipline and ethics deliberations.

5. FINANCE

$$
\text { Chairman: D. W. Smith }
$$

a) In consultation with the Registrar, prepare and submit an operating budget for 1968, on or before April 15, 1968.

b) Pursuing the 1967 Finance Committee's efforts, recommend procedures for permanent management of Association investments.

c) Investigate the Association's fee structure in relation to (a) and (b) above; if a change is recommended, undertake any necessary balloting or other action required.

\section{FOREST TECHNOLOGISTS}

Chairman: D. T. Grant

Meet with graduates of Forest Technology Schools in British Columbia, and members of the Society of Forest Officers, to promote liaison with these groups in the following fields: 
a) Attempting to classify and standardize the Forest Technology courses in British Columbia if possible.

b) Aiding the graduate technologists in forming their own society, and in setting up standards, syllabus, and examinations for those who have not attended these Technology Institutes.

c) Providing a common ground for members of the above groups to form one society, if they so desire.

d) Working with these allied groups in determining and defining "the practice of "orestry" so that there will be no overlapping of functions in the minds of Association members, techno!ogists, or iorest officers.

\section{PUBLIC RELATIONS}

$$
\begin{array}{r}
\text { Chairman: A. Horth, } \\
\text { S. Hope. }
\end{array}
$$

a) Prepare the "Highlights" of Council meetings for distribution by the Registrar, bearing in mind the need for good communications within the Association on most matters, but some security on certain matters.

b) Arrange for representation of the Association at Select Standing Committee hearings and at other appropriate meetings, as directed by Council.

c) Propose measures to present the Forestry profession to the public with reasonable dignity through the press, participation in the Vancouver Forestry Festival, or by other means.

d) In consultation with the Finance Committee, prepare a budget covering expenditures for the above activities.

\section{FOREST POLICY}

$$
\begin{gathered}
\text { Chairman: R. E. Foster } \\
\text { Council Liaison Member: } \\
\text { A. J. Scholefield }
\end{gathered}
$$

a) Within the framework established by the 1967 Policy Committee, present a broad land-use and forestry policy statement to Council, and to the membership in letter ballot form, preferably by June, 1968.

b) Concentrating on issues of current importance as indicated by the Kamloops Workshop and events in B.C., develop more explicit policy statements for study and debate within the broad policy already endorsed.

9. STANDARDS (Including Forestry Pupil Standards and Forestry Faculty Liaison in 1968).

Chairman: W. C. Burch.

a) Examine proposals of the 1967 Standards Committee for possible action.

b) In cooperation with the UBC Forestry Faculty, set up procedures for regular review and improvement of the Forestry Pupil syllabus, and for providing pupils with the best study material. c) Maintain liaison with the Forestry Faculty in connection with (b) above, and to further our common interest in good standards of professional forestry education.

\section{Association of Registered Professional Foresters of New Brunswick}

\section{Committees and Terms of References}

Board of examiners:
R. W. Thompson, Chairman 1967-1968
H. W. Blenis
F. S. Fellows 1967-1968
K. B. Brown 1968-1969
R. A. Redmond 1968-1969

The board shall consider applicants for registration, examine and re-examine such applicants as necessary, and as soon as possible make and file with the secretary-treasurer the certificate recommended whether or not such applicants shall be registered; thereupon the executive shall forthwith consider the recommendation of the board of examiners and, if the executive deems advisable may instruct the secretary-treasurer to notify each applicant of its decision.

\section{Regional Studies Committee (Resource Roads)}

To report to the next Annual Meeting of the Association. The study will include forecasting future needs for resources access roads and provide a map indicating resource road priorities for the next 10 years together with use as to control.

Five groups starting out the study and the chairman of each are as follows:

1. Kedgwick-Bathurst W. L. Johnson

2. Miramichi A. C. Fulcher

3. Saint John - St.

Stephen

4. Fredericton

H. H. Young

5. Edmundston - Plaster

Rock

J. I. MacDonald

Technical Information Committee:

To note the source and substance of Technical Forestry Information descriptive of, and directly pertinent to the management of New Brunswick Forests.
N. T. Wetmore - chairman
W. L. Johnson
J. L. Hall
J. H. Sewell
J. R. Bedard

\section{Change of By-Laws:}

In the interpretation of by-law 14.02 the board of examiners is authorized to use the following footnote as guidance:

"In the interpretation of by-law 14.02 the time spent by an applicant in formal professional study be excluded from the three year time limit following 1st graduation in making application for membership". 


\section{Liste des Comités de la Corporation des Ingénieurs Forestiers de la Province de Québec}

\section{COMITE AVISEUR}

a) Faire des suggestions pratiques au Conseil d'administration sur la politique générale de la Corporation.

b) Préparer le schéma des principales activités scientifiques et sociales du prochain congrès.

c) Commencer la révision de notre principale publication "Le problème forestier du Québec".

Membres du Comité Paul-E. Vézina, président; Jean-Paul R. Dubé; Miroslav Grandtner; Jacques LaRue; Raymond Lord; Lucien Morais

COMITE SUR LA FORMATION DE L'INGENIEUR FORESTIER

a) Continuer l'étude entreprise l'an dernier.

b) Créer un sous-comité qui verrait à étudier la compétence actuelle de l'ingénieur forestier dans l'aménagement récréatif et cynégétique de nos ressources forestières afin de suggérer des moyens pratiques de parfaire cette compétence.

Membres du Comité

Gilbert Tardif, président; Robert Bellefeuille; Gilles Côté; Robert Lafrance; René Rinfret.

\section{COMITE DE LEGISLATION FORESTIERE}

Ce comité terminera l'étude comparative des différents mémoires présentés lors des audiences publiques du Ministère des terres et forêts.

Ce comité devra préparer l'ébauche du mémoire que la Corporation présentera au Ministère des terres et forêts lors des audiences publiques portant sur le "Libre blanc".

Membres du Comité

Renald Provencher, président; Marc Côté; André Demers; Jean Filteau; Michel Lefebvre.

\section{COMITE DE LA PRATIQUE PRIVEE}

a) Continuer l'étude sur la délimitation des cadres de la pratique privée.

b) Etudier la possibilité d'établir une classification parmi les membres de la pratique privée (junior et sénior).

Membres du Comité

Robert-C. Darveau, président; Germain Boucher; André Bouliane; Hugues Fortin; Gilles Walsh.

\section{COMITE DES RELATIONS PROFESSIONNELLES}

Ce comité poursuivra son étude sur les moyens et les mécanismes à mettre en oeuvre pour améliorer les relations entre les membres de la Corporation.

A la suite des études présentées lors du symposium sur le syndicalisme, ce comité devrait ex- plorer davantage la complémentarité qui existe entre syndicat et corporation afin que nous puissions délimiter le rôle précis de notre Corporation dans les domaines qui lui sont propres.

Membres du Comité

Julien Rivest, président; Pete Johnson; Richard Lacasse; Pierre Lefebvre; Marc-V. Mercier.

\section{COMITE DE TERMINOLOGIE FORESTIERE}

Continuer la révision du "Vocabulaire forestier" entreprise l'an dernier en collaboration avec l'Office de la langue française et son directeur, monsieur Maurice Beaulieu.

Membres du Comité

Marius Pineau; Jean Poliquin.

Ontario Professional

Foresters Association

Committees 1967-68

BOARD OF EXAMINERS

D. S. Bruce, Chairman, J. E. Bothwell, Q. F. Hess,

A. S. Michell, J. K. Naysmith, L. A. Smithers.

\section{BY-LAWS*}

A. D. Hall, Chairman.

\section{CONSULTING FORESTERS}

C. J. R. Wilde, Chairman, W. W. Hall, K. W. Horton.

FINANCE

K. W. Hearnden, Chairman, D. S. Bruce, T. E. Mackey.

\section{HONORARY LIFE MEMBERS*}

T. E. Mackey, Chairman.

\section{MEMBERSHIP}

J. D. Hughes, Chairman, G. H. D. Bedell, F. J. Bredle, A. B. Vincent.

\section{NOMINATIONS*}

A. J. Herridge, Chairman.

O.P.F.A.-C.I.F. RELATIONS*

R. M. Dixon, Chairman, G. P. Breckinridge, D. A. Fawcett, S. N. Golder, E. K. Morgenstern, J. R. M. Williams.

\section{PRACTICE AND ETHICS}

G. A. Hamilton, Chairman, E. B. Ayer, A. F. Buell, R. S. Hyslop, G. M. B. Longley, L. A. Smithers, D. G. Yeomans.

PUBLIC INFORMATION

J. D. Coats, Chairman, J. W. Giles, W. R. Grinnell, R. E. Keen, D. V. Love, A. S. Morris, M. B. Price.

\section{SALARY SURVEY}

R. J. Burgar, Chairman, S. T. B. Losee, N. F. Lyon. VOCATIONAL GUIDANCE

J. F. Flowers, Chairman, H. D. Graham, D. E. Honeyborne, E. R. Humphreys, J. C. Jackson.

*Membership not complete, as of Feb. 22, 1968. 